\title{
ANALISIS PENGARUH INFORMASI KEUANGAN PERUSAHAAN DAN NON KEUANGAN PERUSAHAAN TERHADAP TINGKAT UNDERPRICING SAHAM PERDANA DI BURSA EFEK INDONESIA
}

(Studi empiris pada perusahaan yang IPO periode 2018)

\author{
Ulfa Setyaningsih *) \\ Theresia Tyas Listyani **) \\ Manarotul Fatati $* *$ ) \\ *) ulfasetyaningsih26@gmail.com
}

\begin{abstract}
Stock underpricing is a situation where the stock price at the time of supply in the primary market lower than when traded in the secondary market. Stock Underpricing is unfavorable phenomenon for companies that go public, because the funds obtained the company was not optimal. This study aimed to analyze the influence of Earning Per Share (EPS), Debt to Equity Ratio (DER), Underwriter Reputation and Age Companies on the level of Underpricing level at the Indonesia Stock Exchange on the company's IPO period of 2018.

The study design was quantitative research applied causal. The sampling technique used was purposive sampling, with a total sample of 54 and data used are cross section. Data analysis method used is multiple linear regression operated by SPSS 20.0.

The results of this study indicate that the Earning Per Share (EPS) and Debt to Equity Ratio (DER) have no significant effect on the level of underpricing of IPO at the Indonesia Stock Exchange, while Reputation Underwriter and Age Company have significant effect on the level of underpricing of IPO at the Indonesia Stock Exchange.
\end{abstract}

\section{Keywords: Underpricing Shares, Earning Per Share (EPS), Debt to Equity Ratio (DER), Underwriter Reputation, Age Company.}

*) Mahasiswa Skripsi Prodi Analis Keuangan, Jurusan Akuntansi, Politeknik Negeri Semarang

**) Dosen Jurusan Akuntansi, Politeknik Negeri Semarang

\section{PENDAHULUAN}

Pada umumnya setiap perusahaan mempunyai keinginan untuk memperluas dan mengembangkan usahanya. Hal ini dapat dilakukan dengan mengadakan ekspansi usaha. Perusahaan dalam melakukan ekspansi tersebut memerlukan tambahan modal yang cukup besar dan seringkali modal yang diambil dari dalam perusahaan tidak mencukupi, sehingga diperlukan usaha mencari sumber pendanaan dari luar perusahaan. Ada beberapa alternatif yang bisa digunakan perusahaan untuk mendapatkan tambahan modal tersebut diantaranya melalui mekanisme penyertaan yang umumnya dilakukan dengan menjual saham perusahaan kepada publik atau yang disebut dengan go public di pasar modal.

Tandelilin (2010:26) menjelaskan bahwa pasar modal adalah pertemuan antara pihak yang memiliki kelebihan dana dengan pihak yang membutuhkan dana dengan cara 
memperjualbelikan sekuritas. Dari pengertian tersebut mengandung arti bahwa pasar modal adalah lembaga perantara atau intermediary dari masyarakat yang kelebihan dana dengan perusahaan yang membutuhkan dana dengan cara memperjualbelikan sekuritas atau surat-surat berharga.

Perusahaan yang ingin mendapatkan tambahan modal melalui pasar modal, maka perusahaan harus melakukan go public terlebih dahulu. Penawaran umum atau sering pula disebut go public adalah kegiatan penawaran saham atau efek lainnya yang dilakukan oleh emiten (perusahaan yang go public) kepada masyarakat berdasarkan tata cara yang diatur oleh UU Pasar Modal dan Peraturan Pelaksanaannya (Darmadji, 2012:58).

Perusahaan yang akan go public akan melakukan transaksi penawaran umum perdana atau Initial Public Offering atau sering disebut IPO yang dilakukan di pasar perdana atau pasar primer Bursa Efek Indonesia, selanjutnya saham akan diperjualbelikan di pasar sekunder Bursa Efek Indonesia (Lutfianto, 2013).

Masalah yang seringkali timbul dari Initial Public Offering (IPO) adalah terjadinya underpricing saham. Underpricing saham adalah suatu kondisi dimana harga penutupan saham di pasar perdana lebih rendah dibandingkan dengan harga saham yang dijual di pasar sekunder dengan saham yang sama, atau selisih positif harga saham di pasar sekunder dengan harga saham di pasar perdana.

Saat ini dapat dikatakan bahwa perusahaan yang IPO memiliki masalah dengan kinerjanya yang ditunjukkan dengan tingkat underpricing saham perusahaan yang mengalami kecenderungan meningkat selama periode 2013 - 2018. Rata-rata tingkat underpricing saham dapat dilihat dalam grafik berikut ini:

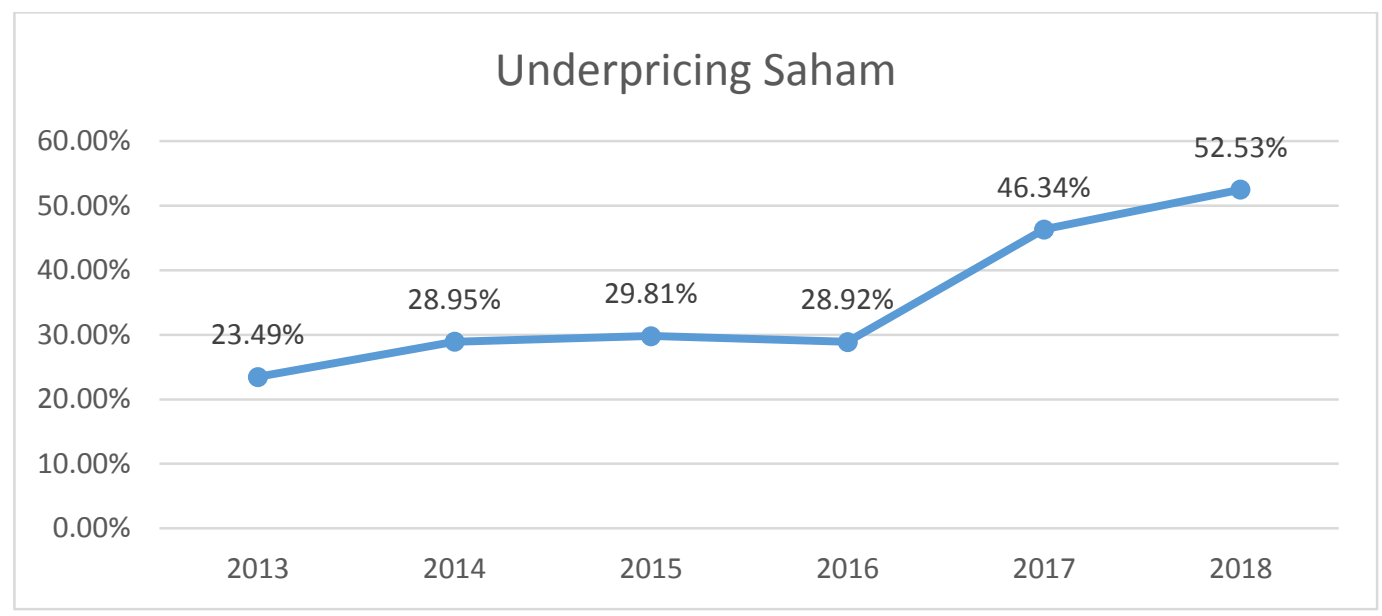

Gambar 1

Grafik Rata-Rata Tingkat Underpricing Saham pada Perusahaan IPO Periode 2013-2018 


\section{Rumusan Masalah}

Berdasarkan pada fenomena bisnis yaitu terjadinya kenaikan tingkat underpricing saham pada perusahaan yang IPO periode 2013-2018, maka dikembangkan masalah penelitian sebagai berikut: "Bagaimana menurunkan underpricing saham pada perusahaan yang IPO melalui Earning Per Share (EPS), Debt to Equity Ratio (DER), Reputasi Underwriter, Umur Perusahaan ?".

\section{Tujuan Penelitian}

Adapun tujuan dari penelitian ini adalah untuk menganalisis pengaruh dan signifikansi Earning Per Share (EPS), Debt to Equity Ratio (DER), Reputasi Underwriter, Umur Perusahaan secara parsial terhadap underpricing saham.

\section{KAJIAN TEORI}

Dalam pembahasan kajian teori, terdapat tiga sub bab pendukung yaitu pengertian variabel, model penelitian dan hipotesis penelitian. Dan penjelasan dari ke tiga sub pendukung tersebut adalah sebagai berikut:

\section{Underpricing Saham}

Underpricing merupakan salah satu fenomena yang sering terjadi ketika perusahaan akan melakukan IPO (Initial Public Offfering). Saham yang nantinya ditawarkan di pasar sekunder sebelumnya akan ditawarkan di pasar perdana. Fenomena harga rendah (underpricing) terjadi karena harga penawaran perdana ke publik secara rerata murah (Jogiyanto, 2010 dalam Maukar, 2013:26). Adapun formula yang dapat digunakan untuk menghitung underpricing saham adalah sebagai berikut:

$$
U P=\frac{\text { Closing Price Hari Pertama di Pasar Sekunder-Harga Penawaran Perdana }}{\text { Harga Penawaran Perdana }} \times 100
$$

\section{Earning Per Share (EPS)}

Menurut Fahmi (2012:138), Earning Per Share (EPS) atau pendapatan saham per lembar adalah bentuk pemberian keuntungan yang diberikan kepada para pemegang saham dari setiap lembar saham dimiliki. Dari pengertian tersebut diketahui bahwa Earning Per Share (EPS) menunjukkan seberapa besar kemampuan perusahaan untuk memberikan pengembalian (return) kepada pemilik perusahaan. Adapun formula yang dapat digunakan untuk menghitung Earning Per Share (EPS) adalah sebagai berikut:

$$
\text { EPS }=\frac{\text { Laba bersih }}{\text { Jumlah saham beredar }}
$$




\section{Debt to Equity Ratio (DER)}

Menurut Kasmir (2010:157) menyatakan, debt to equity ratio merupakan rasio yang digunakan untuk menilai utang dan ekuitas. Rasio ini dicari dengan cara membandingkan antara seluruh utang dengan seluruh ekuitas. Rasio ini berguna untuk mengetahui jumlah dana yang disediakan peminjam (kreditur) dengan pemilik perusahaan. Dengan kata lain, rasio ini berfungsi untuk mengetahui setiap rupiah modal sendiri yang dijadikan untuk jaminan utang. Adapun formula yang dapat digunakan untuk menghitung DER adalah sebagai berikut:

$$
\text { Debt to Equity Ratio ( DER ) }=\frac{\text { Total utang }}{\text { Total modal }}
$$

\section{Reputasi Underwriter}

Menurut Pasal No. 17 UU No. 8 Tahun 1995 tentangn Pasar Modal, underwriter adalah pihak yang membuat kontrak dengan emiten untuk melakukan penawaran umum perdana bagi kepentingan emiten dengan atau tanpa kewajiban untuk membeli sisa efek yang terjual. Penjamin emisi atau underwriter merupakan perantara antara perusahaan yang membutuhkan modal dan investor sebagai pemodalnya. Variabel pengukuran reputasi underwriter terbaik ditetapkan berdasarkan data 50 besar active IDX member in total trading frequency, selanjutnya data tersebut diambil 10 besar dan diterapkan kepada data underwriter yang digunakan oleh masing-masing sampel perusahaan, apakah perusahaan tersebut menggunakan jasa underwriter terbaik atau tidak. Sedangkan teknik yang digunakan untuk pengukuran menggunakan variabel dummy, yang mana perusahaan yang menggunakan jasa underwriter terbaik akan diberikan nilai 1 (satu) sebaliknya apabila perusahaan tidak menggunakan jasa underwriter terbaik akan diberi nilai 0 (nol).

\section{Umur Perusahaan}

Umur perusahaan menggambarkan kemampuan perusahaan tetap dapat bertahan hidup dan banyaknya informasi yang dapat diterima publik dari perusahaan (Suyatmin dan Sujadi, 2006 dalam Permatasari, 2014). Semakin lama umur perusahaan, maka semakin banyak informasi yang telah diperoleh masyarakat tentang perusahaan tersebut. Adapun formula yang dapat digunakan untuk menghitung umur perusahaan adalah sebagai berikut:

Age $=$ Tahun perusahaan IPO - Tahun perusahaan berdiri

\section{Model Penelitian}

Berdasarkan landasan teori dan penelitian terdahulu mengenai hubungan antara variabel independen (EPS, DER, Reputasi Underwriter, dan Umur Perusahaan) dengan variabel 
dependen (Underpricing saham) di atas, maka dapat dikembangkan model penelitian seperti tampak pada Gambar 2.1 berikut ini :

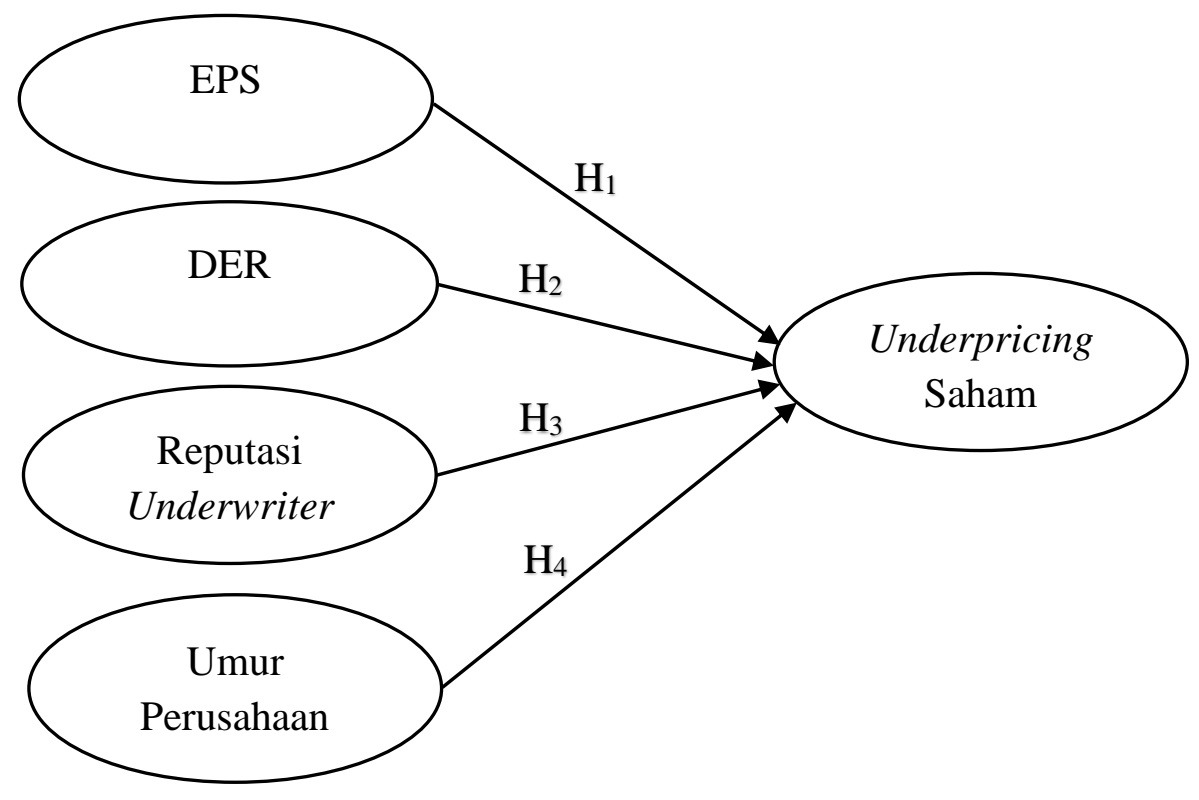

Gambar 2.1

Model Penelitian

Sumber: Retnowati (2013), Hapsari \& Mahfud (2012), Pahlevi (2014), Kristiantari (2013), Nadia dan Daud (2017), Prawesti dan Indrasari (2014), Arman (2012), Rastiti dan Stephanus (2015).

\section{Hipotesis}

Mengacu pada rumusan masalah, dan tujuan penelitian, maka hipotesis penelitian ini adalah variabel Earning Per Share (EPS), Debt to Equity Ratio (DER), Reputasi Underwriter, dan Umur Perusahaan secara parsial mempunyai pengaruh dan signifikan terhadap underpricing saham.

\section{METODE}

Metode penelitian merupakan sebuah proses atau cara ilmiah untuk mendapatkan data yang digunakan untuk keperluan penelitian. Dalam metodologi penelitian membahas tentang:

\section{Populasi dan Sampel}

Populasi dalam penelitian ini adalah 57 perusahaan yang melaksanakan Initial Public Offering di Bursa Efek Indonesia tahun 2018. Sampel penelitian ini adalah 54 perusahaan yang mengalami underpricing saham dan diambil dengan menggunakan teknik purposive sampling.

\section{Model Pengumpulan Data}

Dalam penelitian ini menggunakan metode pengumpulan data secara metode studi pustaka dan metode dokumentasi. Metode studi kepustakaan (library research) digunakan 
untuk mencari referensi yang bersumber dari buku-buku literatur, jurnal dan artikel yang menunjang dalam penelitian. Sementara itu, data sekunder yang digunakan dalam penelitian ini dikumpulkan dengan menggunakan metode dokumentasi, yaitu dengan cara mencari informasi yang berasal dari catatan penting baik dari lembaga atau organisasi maupun dari perorangan.

\section{Metode Analisis Data}

Metode analisis yang digunakan berupa uji statistik deskriptif, estimasi model regresi, uji asumsi klasik (uji linearitas, uji normalitas, uji multikolonieritas, uji heteroskedastisitas), uji kelayakan model (uji statistik F, uji statistik $t$, dan koefisien determinasi $\left(\mathrm{R}^{2}\right)$ ).

\section{HASIL DAN PEMBAHASAN}

Pada penjelasan hasil dan pembahasan menjelaskan tentang tahap-tahap analisis yang digunakan dalam penelitian dan membahas hubungan antar variabel. Adapun tahapan-tahapan yang digunakan dalam penelitian ini adalah sebagai berikut:

\section{Statistik Deskriptif}

Sugiyono (2010:207) menjelaskan bahwa statistik deskriptif adalah statistik yang digunakan untuk menganalisis data dengan cara mendeskripsikann atau menggambarkan data yang telah terkumpul sebagaimana adanya tanpa bermaksud membuat kesimpulan yang berlaku untuk umum atau generalisasi. Hasil statistik deskriptif untuk variabel independen Earning Per Share (EPS), Debt to Equity Ratio (DER), Reputasi Underwriter, dan Umur Perusahaan dapat dilihat pada tabel sebagai berikut:

Tabel 1

Statistik Deskriptif

Descriptive Statistics

\begin{tabular}{|l|r|r|r|r|r|}
\hline & N & Minimum & Maximum & Mean & $\begin{array}{c}\text { Std. } \\
\text { Deviation }\end{array}$ \\
\hline Underpricing & 54 &, 45 & 70,00 & 52,5272 & 19,36653 \\
EPS & 54 & $-72,26$ & 10741,91 & 355,7083 & 1550,34330 \\
DER & 54 &, 06 & 78,42 & 4,4541 & 12,30836 \\
RUD & 54 &, 00 & 1,00 &, 1852 &, 39210 \\
AGE & 54 &, 00 & 64,00 & 16,1481 & 13,80512 \\
Valid N & 54 & & & & \\
(listwise) & & & & & \\
\hline
\end{tabular}

Sumber : Data Sekunder yang diolah (2019) 


\section{Estimasi Model Regresi}

Estimasi model regresi merupakan estimasi model regresi menjelaskan kemampuan variabel independen untuk memprediksi keberadaan variabel dependen. Persamaan dari estimasi regresi adalah sebagai berikut :

$\mathrm{UDPC}=$ 65,797+ 0,001 EPS - 0,163 DER- 24,568 RUD - 0,525 AGE + e

\section{Uji Asumsi Klasik}

Dalam tahap pengujian asumsi klasik terdapat empat uji pendukung yaitu uji linearitas, uji normalitas, uji multikolinearitas, dan uji heteroskedastisitas. Penjelasan dari ke empat uji pendukung tersebut adalah:

\section{Uji Linearitas}

Uji ini digunakan untuk melihat apakah spesifikasi model yang digunakan sudah benar atau tidak, apakah fungsi yang digunakan dalam studi empiris sebaiknya berbentuk linear, kuadrat atau kubik (Ghozali, 2011). Berdasarkan hasil olah data dapat diketahui bahwa nilai D - W sebesar 1,833 > 1,4069 (dL pada tabel $\mathrm{D}-\mathrm{W})$, dengan $\mathrm{n}=54$ dan $\mathrm{k}=4$, maka dapat diketahui hasil estimasi model tidak terjadi autokorelasi positif, sehingga dapat dikatakan estimasi model yang dihasilkan adalah model linear.

\section{Uji Normalitas}

Menurut Ghozali (2009:107) uji normalitas bertujuan untuk menguji apakah dalam model regresi, variabel pengganggu atau residual memiliki distribusi normal. Berdasarkan hasil uji statistik non-parametik Kolmogorov - Smirnov (K-S) menunjukkan nilai yang signifikan yaitu sebesar 0,070 lebih besar dari 0,05. Hal ini menunjukkan data dalam penelitian ini berdistribusi secara normal.

\section{Uji Multikolonieritas}

Uji multikolonieritas bertujuan untuk menguji apakah model regresi ditemukan adanya korelasi antar variabel bebas (independen) atau tidak. Berdasarkan hasil olah data dapat diketahui bahwa variabel yang terdiri dari Earning Per Share (EPS), Debt to Equity Ratio (DER), Reputasi Underwriter, Umur Perusahaan menunjukkan bahwa tidak ada yang mempunyai nilai tolerance $<0,10$ dan VIF $>10$. Oleh karena itu dapat diambil kesimpulan bahwa tidak terjadi multikolonieritas.

\section{Uji Heteroskedastisitas}

Uji heteroskedastisitas bertujuan menguji apakah dalam model regresi terjadi ketidaksamaan variance dan residual satu pengamatan ke pengamatan lain. Berdasarkan hasil 
olah data dapat diketahui bahwa semua variabel independen memiliki nilai signifikansi lebih dari $5 \%$, maka dapat disimpulkan bahwa tidak terdapat masalah heteroskedastisitas.

\section{Uji Kelayakan Model}

Menurut Ghozali (2009:14) uji kelayakan model sering disebut dengan Goodness of fit tujuannya untuk menguji ketepatan fungsi regresi sampel dalam menaksir nilai aktual. Secara statistik, setidaknya ini dapat diukur dari nilai uji $\mathrm{F}$, uji t dan uji koefisien determinasi $\left(\mathrm{R}^{2}\right)$.

\section{Uji F}

Uji statistik F pada dasarnya menunjukkan apakah semua variabel independen atau variabel bebas yang dimasukkan dalam model mempunyai pengaruh secara bersama-sama terhadap variabel dependen atau terikat. Berdasarkan hasil olah data diketahui bahwa $F_{\text {hitung }}$ $(5,422)>$ dari $F_{\text {tabel }}(2,56)$, sehingga $F_{\text {hitung }}>F_{\text {tabel }}$. Hal ini berarti bahwa model memiliki Goodness of fit yang baik karena Debt to Equity Ratio (DER), Earning Per Share (EPS), Reputasi Underwriter, Umur Perusahaan berpengaruh secara simultan (bersama-sama) terhadap underpricing saham. Selain itu hasil di atas juga menunjukkan bahwa tingkat signifikansinya sebesar 0,001 <0,05, yang berarti bahwa pengaruh simultan Earning Per Share (EPS), Debt to Equity Ratio (DER), Reputasi Underwriter, Umur Perusahaan adalah signifikan. Dengan kata lain model penelitian ini layak untuk digunakan sebagai model pemecahan masalah penelitian.

\section{Uji t}

Uji t dilakukan untuk melihat seberapa besar masing-masing variabel independen mampu menjelaskan variabel dependen. Hasil uji t pada penelitian ini dapat dilihat pada tabel sebagai berikut:

\section{Tabel 2}

Uji t

Coefficients $^{\mathbf{a}}$

\begin{tabular}{|c|c|c|c|c|c|c|}
\hline \multirow{2}{*}{\multicolumn{2}{|c|}{ Model }} & \multicolumn{2}{|c|}{$\begin{array}{c}\text { Unstandardized } \\
\text { Coefficients }\end{array}$} & \multirow{2}{*}{$\begin{array}{c}\text { Standardized } \\
\text { Coefficients } \\
\text { Beta }\end{array}$} & \multirow[t]{2}{*}{$\mathrm{T}$} & \multirow[t]{2}{*}{ Sig. } \\
\hline & & B & Std. Error & & & \\
\hline \multirow{5}{*}{1} & (Constant & 65,797 & 4,093 & & 16,075 & ,000 \\
\hline & EPS & ,001 & ,002 & ,108 & ,866 & 391 \\
\hline & DER &,- 163 & , 192 &,- 103 &,- 848 & ,401 \\
\hline & RUD & $-24,568$ & 6,234 &,- 497 & $-3,941$ & ,000 \\
\hline & AGE &,- 525 &, 172 &,- 374 & $-3,048$ & ,004 \\
\hline
\end{tabular}

a. Dependent Variable: Underpricing

Sumber : Data Sekunder yang diolah (2019) 
Dalam pengujian $\mathrm{t}$ ini, suatu variabel diterima karena berpengaruh dan signifikan terhadap variabel dependen apabila pada hasil pengujian $t$ menghasilkan nilai $t_{h i t u n g}>t_{\text {tabel }}$ atau $-\mathrm{t}_{\text {hitung }}<-\mathrm{t}_{\text {tabel }}$ dan signifikansinya $<0,05$. Berdasarkan kedua syarat tersebut, dapat diketahui terdapat dua variabel independen yang diterima sesuai hipotesis berpengaruh dan signifikan yaitu varibel Earning Per Share (EPS), dan Debt to Equity Ratio (DER), sedangkan untuk variabel Reputasi Underwriter, dan Umur Perusahaan ditolak karena tidak memenuhi ke dua syarat diatas.

\section{Uji Koefisien Determinasi $\left(\mathbf{R}^{\mathbf{2}}\right)$}

Uji $\mathrm{R}^{2}$ ini digunakan untuk mengukur seberapa besar kemampuan model untuk menjelaskan goodness of fitnya dari sisi kemampuan variabel-variabel yang telah dipilih didalam suatu model untuk memprediksi atau menjelaskan keberadaan variasi variabel dependen. Berdasarkan hasil olah data dapat diketahui bahwa model penelitian yang diajukan memiliki kelayakan yang tidak tinggi karena variasi variabel-variabel independen yang digunakan yaitu variasi variabel Earning Per Share (EPS), Debt to Equity Ratio (DER), Reputasi Underwriter, Umur Perusahaan hanya mampu menjelaskan keberadaan variabel dependennya yaitu underpricing saham sebesar 25,00\%, dimana sebesar 75,00\% dapat dijelaskan variasi variabel lain di luar model.

\section{Interpretasi Model}

Setelah estimasi model regresi linear berganda dilakukan dan diuji pemenuhan syaratnya (uji asumsi klasik) serta kelayakan modelnya, maka tahap terakhir adalah menginterpretasikannya. Interpretasi model merupakan suatu upaya penjelasan model penelitian yang bersifat teoritis ke dalam model penelitian praktis sebagai pemecah masalah penelitian. Hasil estimasi model regresi dalam penelitian ini menunjukkan hasil sebagai berikut:

\section{$\mathrm{UDPC}=$ 65,797 + 0,001 EPS - 0,163 DER- 24,568 RUD - 0,525 AGE + e}

\section{Pembahasan}

Berdasarkan hasil pengujian hipotesis 1 menunjukkan bahwa variabel Earning Per Share (EPS) tidak memiliki pengaruh dan tidak signifikan terhadap Underpricing Saham. Hal ini dikarenakan semakin tinggi Earning Per Share (EPS) memberikan indikasi bahwa semakin besar keuntungan yang diperoleh perlembar saham, dengan asumsi outstanding sharesnya tetap atau perusahaan semakin besar dalam memperoleh laba. Apabila perusahaan memberikan laba (earning per share) terlalu banyak kepada investor dimungkinkan akan membuat perusahaan kesulitan untuk berkembang pesat karena semua dana hasil pendapatan perusahaan diberikan 
kepada pemegang saham, sehingga perusahaan tidak memiliki tambahan dana untuk berkembang. Hal ini membuat ketidakpastian perusahaan meningkat dan bisa memperbesar terjadinya tingkat underpricing saham.

\section{Pengaruh Debt to Equity Ratio (DER) terhadap tingkat Underpricing Saham Perdana di Bursa Efek Indonesia}

Berdasarkan hasil pengujian hipotesis 2 menunjukkan bahwa variabel Debt to Equity Ratio (DER) tidak memiliki pengaruh dan tidak signifikan terhadap Underpricing Saham. . Hal ini dikarenakan investor dalam menanamkan modalnya pada perusahaan IPO tidak selalu mempertimbangkan Debt to Equity Ratio (DER), tetapi kemungkinan investor hanya melihat dari sisi hutangnya saja sehingga Debt to Equity Ratio (DER) tidak bisa dijadikan tolok ukur ketidakpastian IPO. Hal ini membuat ketidakpastian perusahaan menjadi rendah dan bisa memperkecil terjadinya tingkat underpricing saham.

\section{Pengaruh Reputasi Underwriter terhadap tingkat Underpricing Saham Perdana di Bursa} Efek Indonesia

Berdasarkan hasil pengujian hipotesis 3 menunjukkan bahwa variabel Reputasi Underwriter memiliki pengaruh dan signifikan terhadap Underpricing Saham. Hal ini dikarenakan semakin tinggi Reputasi Underwriter menunjukkan bahwa underwriter yang bereputasi tinggi lebih berani memberikan harga yang tinggi sebagai konsekuensi dari kualitas penjaminannya, sehingga tingkat underpricing menjadi rendah.

Pengaruh Umur Perusahaan terhadap tingkat Underpricing Saham Perdana di Bursa Efek Indonesia

Berdasarkan hasil pengujian hipotesis 4 menunjukkan bahwa variabel Umur Perusahaan memiliki pengaruh dan signifikan terhadap Underpricing Saham. Hal ini dikarenakan semakin lama umur perusahaan, maka informasi mengenai perusahaan tersebut semakin besar dan memperkecil ketidakpastian pasar yang pada akhirnya akan menurunkan tingkat underpricing saham.

\section{PENUTUP}

Pada bab penutup, terdapat tiga pembahasan yaitu tentang kesimpulan, keterbatasan penelitian dan saran. Adapun penjelasan dari kesimpulan, implementasi penelitian keterbatasan penelitian dan saran adalah sebagai berikut:

\section{Kesimpulan}

Kesimpulan dalam penelitian ini adalah sebagai berikut : 
1. Secara parsial variabel Earning Per Share (EPS) dan Debt to Equity Ratio (DER) tidak berpengaruh signifikan terhadap Underpricing Saham.

2. Secara parsial variabel Reputasi Underwriter dan Umur Perusahaan berpengaruh signifikan terhadap Underpricing Saham.

\section{Implementasi Penelitian}

Berdasarkan hasil analisis dan kesimpulan, penelitian ini diharapkan dapat memberikan manfaat bagi perusahaan sebagai berikut:

1. Hasil penelitian ini diharapkan dapat memberikan manfaat bagi perusahaan untuk memberikan perhatian khusus atas fenomena underpricing. Hal ini perlu diperhatikan karena bila perusahaan mengalami underpricing maka dana yang di dapat dari pelaksanaan IPO tidak maksimum dan sangat merugikan perusahaan yang melakukan IPO. Dikatakan sangat merugikan karena perusahaan yang melakukan go public hanya mendapatkan dana pada saat melakukan IPO di Bursa Efek Indonesia, sehingga perusahaan perlu memperhatikan faktor-faktor yang mempengaruhi fenomena underpricing ini, terutama penggunaan jasa underwriter. Dalam penelitian ini dibuktikan bahwa reputasi underwriter berpengaruh signifikan terhadap tingkat underpricing saham perdana di Bursa Efek Indonesia.

2. Perusahaan juga perlu memperhatikan faktor umur perusahaan, dimana umur perusahaan menunjukkan seberapa lama perusahaan mampu bertahan dalam persaingan bisnis. Semakin lama umur suatu perusahaan, maka semakin banyak informasi yang dimiliki masyarakat tentang perusahaan itu dibanding perusahaan yang baru berdiri.

\section{Keterbatasan Penelitian}

1. Hasil uji model regresi yang menunjukkan bahwa variabel Earning Per Share (EPS) dan Debt to Equity Ratio (DER) memiliki prediksi yang rendah terhadap tingkat underpricing saham perdana di Bursa Efek Indonesia. Hal tersebut ditunjukkan dari besarnya nilai signifikansi varibel Earning Per Share (EPS) dan Debt to Equity Ratio (DER) di atas 0,05. Hal ini berarti Earning Per Share (EPS) dan Debt to Equity Ratio (DER) tidak terlalu mempengaruhi penurunan tingkat underpricing saham.

2. Penelitian ini menggunakan 4 variabel independen sehingga didapat nilai Adjusted $R$ Square hanya sebesar 0,25 atau 25\%. Hal ini bermakna variabel-variabel independen dalam penelitian ini masih sangat terbatas, sedangkan masih banyak variabel-variabel lain yang mungkin berpengaruh terhadap tingkat underpricing saham perdana di Bursa Efek Indonesia. 
3. Ada keterbatasan waktu dan biaya dalam melakukan penelitian, sehingga dalam penelitian ini menggunakan empat variabel yaitu Earning Per Share (EPS), Debt to Equity Ratio (DER), reputasi underwriter, dan umur perusahaan (Jogiyanto, 2010:35).

\section{Saran}

Beberapa saran untuk agenda penelitian mendatang yang dapat diberikan dari penelitian ini antara lain:

1. Penelitian selanjutnya dapat menambah beberapa variabel lain seperti reputasi auditor, prosentase penawaran, ukuran perusahaan, kepemilikan saham lama, jenis industri, Return on Asset (ROA), Current Ratio (CR) seperti dalam penelitian Hapsari dan Mahfud (2012), Pahlevi (2014), Prawesti dan Indrasari (2014), Rastiti dan Stephanus (2015).

2. Pada penelitian mendatang disarankan menambah periode waktu yang lebih lama, misalnya periode 2013-2019 agar hasil penelitian dapat menjadi rujukan terkait fenomena underpricing saham yang lebih baru.

\section{DAFTAR PUSTAKA}

Arman, Agus. 2012. "Pengaruh Umur dan Ukuran Perusahaan, Reputasi Underwriter dan Return On Equity Terhadap Tingkat Underpricing Saham di Bursa Efek Indonesia”. Proceeding for call paper pekan ilmiah dosen FEB, Makasar.

Darmadji, Tjiptono dan Hendi M. Fakhrudin. 2012. Pasar Modal di Indonesia Pendekatan Tanya Jawab. Edisi Kedua. Jakarta: Salemba Empat.

Fahmi, Irham. 2012. Pengantar Pasar Modal. Bandung: Alfabeta.

Ghozali, Imam. 2011. Ekonometrika. Semarang: Badan Penerbit Undip

Hapsari, Venantia Anintya dan Mahfud, M. Kholiq. 2012. “Analisis Faktor -Faktor yang Mempengaruhi Underpricing Saham pada Penawaran Umum Perdana Di BEI Periode 2008-2010”. Diponegoro Journal of Management, Volume 1, No.1, Semarang.

Lutfianto, Ary Sukma. 2013. "Determinan Initial Return Saham Go Public Tahun 2006-2011”. Jurnal Ilmu Manajemen, Volume 1, No.1, Surabaya.

Nadia, Riska dan Rulfah M.Daud. 2017. "Pengaruh Informasi Keuangan dan Non Keuangan Terhadap Initial Return Pada Perusahaan yang Melakukan Penawaran Umum Saham Perdana di Bursa Efek Indonesia Periode 2014-2016”. Jurnal Ilmiah Mahasiswa Ekonomi Akuntansi (JIMEKA), Volume 2, Nomor 3, Aceh. 
Pahlevi, Reza Widhar. 2014. "Analisis Faktor-Faktor yang Mempengaruhi Underpricing Saham pada Penawaran Saham Perdana di Bursa Efek Indonesia”. Jurnal Siasat Bisnis, Volume 18, No. 2, Jakarta.

Prawesti, Linggar dan Arum Indrasari. 2014. "Informasi Akuntansi dan Non Akuntansi Terhadap Initial Return Saham”. Jurnal Akuntansi dan Investasi, Volume 15, Nomor 1, Yogyakarta.

Retnowati, Eka. 2013. "Penyebab Underpricing Pada Penawaran Saham Perdana di Indonesia". Accounting Analysis Journal, Volume 2, No 2, Semarang.

Sugiyono. 2010. Metode Penelitian Pendidikan Pendekatan Kuantitatif, Kualitatif, dan R\&D. Bandung: Alfabeta.

Tandelilin, Eduardus. 2010. Portofolio dan Investasi Teori dan Aplikasi. Edisi Pertama. Yogyakarta: Kanisius. 